\title{
UPBRINGING AND EDUCATION AS FACTORS OF HUMAN CAPITAL DEVELOPMENT
}

\author{
${ }^{1}$ A. Sagikyzy, ${ }^{2}$ M. Shurshitbay, ${ }^{3} Z$. Akhmedova
}

\begin{abstract}
The concept of human capital development has been actively developed by the UN since the end of the twentieth century, the main principle of which is to expand the opportunities of each person to realize their potencies and aspirations, to lead a healthy, full-fledged creative life. And this, in turn, is the main meaning and purpose of the socio-economic development of modern society. The criterion of social development is thus the individual. Understanding this idea at the national level has been reflected in a series of national reports on human development in Kazakhstan published in recent years.

The formation of human capital involves the humanization of both the educational process, i.e., the creation of conditions aimed at the disclosure and development of the individual's abilities, his positive self-realization. The goal of education is the need to develop a value-oriented personality. The idea of humanization contributes to the renewal of the process of education in social institutions, which should be carried out through the formation of educational systems.

Keywords: the Concept of Human Capital, Personality, Humanization of the Educational Process, Spiritual and Moral Potential, Self-Realization, Personality Formation, Initiative Person, Creativ-

${ }^{1} \mathrm{Al}$-Farabi Kazakh National University, Institute for Philosophy, Political Science and Religion Studies of the CS MES RK, Almaty, Kazakhstan

${ }^{2}$ Sarsen Amanzholov East Kazakhstan University, Ust-Kamenogorsk, Kazakhstan

${ }^{3}$ Bukhara State Medical Institute, Bukhara, Uzbekistan

Corresponding Author: A.Sagikyzy, ayazhan@list.ru

Reference to this article: Sagikyzy A., Shurshitbay M., Akhmedova Z. Upbringing and Education as Factors of Human Capital Development // Adam alemi. - 2021. - No. 2 (88). - P. 18-25. ity.
\end{abstract}

This research was funded by the SC MES RK (Grant No. AP09259797 «The processes of religiousization in Kazakhstan: specifics, trends, impacts on the development of society and human capital (interdisciplinary analysis)»)

\section{Тәрбие және білім беру адами капиталды дамытудың факторлары ретінде}

Аннотация. Біріккен Ұлттар Ұйымы XX ғасырдың аяғынан бастап адами капитал тұжырымдамасын белсенді түрде дамыту тұжырымдамасын белсенді түрде әдамыта бастады. Оның басты қағидасы - әрбір адамның әлеуеті мен мақсаттарын жүзеге асыруға және салауатты, толыққанды шығармашылық өмір салтын ұстану мүмкіндіктерін кеңейту. Бұл өз кезегінде, қазіргі қоғамның әлеуметтік-экономикалық дамуының басты мазмұны мен мақсаты Мемлекеттік дамудың өлшемі - жеке тұлға. Жеке тұлғаның әлеуметтік, экономикалық, рухани-шығармашылық тұрғыдан дамуы сол мемлекеттің дамуының көрсеткіші екені белгілі. Бұл идеяның ұлттық деңгейде ұғынылуы соңғы жылдарда Қазақстанда жарияланған адам әлеуетінің дамуы туралы жалпыұлттық баяндамалар сериясынан көрініс тапқан.

Адам капиталының қалыптасуы оқыту мен тәрбиелеу процесін гуманизациялауды білдіреді, 
жеке тұлғаның қабілеттерін ашуға және дамытуға, әр адамның шығармашылығын жүзеге асыруға бағытталған жағдайлардың жасалуымен байланысты. Тәрбиенің мақсаты құндылыққа бағдарланған тұлғаны дамыту қажеттілігі болып табылады. Гуманизация идеясы білім беру жүйесін қалыптастыру арқылы жүзеге асырылатын әлеуметтік институттардағы оқу процесін жаңартуға ықпал етеді.

Түйін сөздер: адами капитал туралы түсінік, жеке тұлға, білім беру және оқу процесін гуманизациялау, рухани-адамгершілік әлеует, өзін-өзі тану, жеке тұлғаны қалыптастыру, бастамашылдық, шығармашылық.

\section{Воспитание и образование как факторы развития человеческого капитала}

Аннотация. Концепция развития человеческого капитала с конца XX столетия активно разрабатывается $\mathrm{OOH}$, основным принципом которой является расширение возможностей каждого человека реализовывать свои потенции и устремления, вести здоровую, полноценную творческую жизнь. А это, в свою очередь, является главным смыслом и целью социально-экономического развития современного общества. Критерием общественного развития является, таким образом, личность. Осмысление этой идеи на национальном уровне нашло свое выражение в серии общенациональных докладов о развитии человеческого потенциала в Казахстане, опубликованных в течение последних лет.

Формирование человеческого капитала предполагает гуманизацию и образовательного и воспитательного процесса, т.е. создание условий, направленных на раскрытие и развитие способностей личности, его позитивную самореализацию. А целью воспитания становится необходимость развития ценностно-ориентированной личности. Идея гуманизации способствует обновлению процесса воспитания в социальных институтах, которое должно осуществляться через формирование воспитательных систем.

Ключевые слова: концепция человеческого капитала, личность, гуманизация образовательного и воспитательного процесса, духовно-нравственный потенциал, самореализация, формирование личности, инициативный человек, творчество.

\section{Introduction}

Now there is no doubt that the effective development of the economy of any modern state depends, first of all, on the development of human capital. The stable economic development of the country is ensured by investments in education, upbringing and training of professional personnel. The modernization process requires the effective investment and use of all resources for human development.

Modern research has shown that human capital is a functional component of innovative production, and the socioeconomic development of the country is possible only on its basis. According to many experts, the welfare of the nation, the health of the population depends on education. Based on this situation, we can conclude that the educational level and qualifications of people determine the socio-economic development of the state and its perspective positions. This is not difficult to understand, since national wealth is created by the labor activity of people.

The competitiveness of a country is determined by the physical and intellectual abilities of each citizen to work. After all, a person is a producer of material and spiritual goods.

The factors influencing the formation of high-quality human capital are, first of all, the upbringing of the individual, his spiritual and moral development and education.

UNESCO research has shown that education has a significant impact (at the rate of $60 \%$ ) on income levels. This indicates the undeniable influence of education, basic, professional, on the quality of life of a person.

The transition of the Republic of Kazakhstan to an innovative sociallyoriented type of development involves the development of human capital. The 
assessment of the degree of development of a country is based on its ability to include human capital in innovative processes in all spheres of society.

\section{Methodology}

The creation of its own competitive human capital in the Republic of Kazakhstan on the basis of improving education, including socio-humanitarian, professionalism, intelligence and health of people is the main link set in the Strategy «Kazakhstan-2050» For research, such methods as philosophical conceptualization and socio-humanitarian interpretation, activity and value approaches, the principle of integrity and development were applied.

\section{Discussion}

J.-F. Lyotard defined postmodernism as the era of the end of "great stories». From now on, no authoritative text, no religious or philosophical teaching can become the basis for the formation of a single valuenormative complex that determines the structuring of the socio-political sphere of society. According to A. S. Panarina, «postindustrial society marks the turn of the economy to a new anthropocentrism: the revenge of free entrepreneurial initiative over the anonymous rationality of Large Apparatuses - «scientifically organized», but in fact bureaucratic management systems» [1, p. 215]. The subject of this turn is the petty bourgeois - the «economic man», who does not recognize other instructions, values and norms, except for the market. Describing the everyday background of the life of modern society, Z. Bauman writes: "All of us, to one degree or another, perceive the world in which we live as unreliable, full of risks and dangers. Our social position, our work, the market price of our skills and abilities, our partners, neighbors and friends on whom you can rely - all this is unstable and vulnerable, all this is so unlike a calm harbor where you could anchor your trust» [2, p. 96]. In this «risk society» (E. Giddens, W. Beck), the reliance of activity on the eternal and unchangeable essences of the religious and metaphysical systems of the past becomes obviously irrational.

The economic worldview of the petty bourgeois as a product of a special type of culture and civilization, according to A. S. Panarin, is based on the picture of an "economy with a human face», in the center of which stands a sovereign individual - a producer and a consumer - independent and unaccountable in their decisions. However, not only the moral idealism of all times, but also moral intuition testify to the fundamental inauthenticity, the internal moral impossibility of choosing a line of behavior that actively pursues personal economic interests (despite the fact that in everything that concerns common interests, it is permissible to be uninitiative and cynically immoral) declares the realization of genuine freedom, the highest motive for activity and the basis of its socio-moral legitimacy.

As is well known, I. Kant characterized the civil society based on market mechanisms as a system of «antagonism of ill-natured sociability». Only in the realization of this mechanism of establishing and maintaining an external law-like order, which forces people, including against their will, to enter into a civil union, can a person rise to the realization of his true freedom and moral duty, which have nothing to do with the conditional imperatives of a utilitarian and pragmatic nature. The realization of the ultimate goal of nature, according to which a person must realize himself as a free moral being, is that "pathologically forced consent to life in society", or a normative legal order devoid of moral unconditionality as "freedom under external laws», freedom that needs legal patronage, must eventually be transformed into a «moral whole « [3, p.12-13].

Kant showed that the self-regulating system of civil society atomistics «acts like an automaton». According to Hegel, in civil society, the integral objective spirit «disintegrates» into an abstract set of subjects that are mutually separate from each other and from their own moral 
substance. The result is a «system of social atomistics» in which "everything seems to be left to the will of the individual», and the particular interests of the individuals are the ultimate goal of their integration into society. But this «objective appearance» of the independent existence of atomized social subjects is in reality entirely and variously mediated by a form of spiritual universality that integrates all the structures and elements of civil society into a rational whole. «The whole is the ground of mediation, on which all particulars, all the accidents of birth and happiness give themselves freedom, into which the waves of all passions flow ...» [4, p.211].

In full agreement with the conclusions of Kant and Hegel, the analysis conducted by J. Baudrillard testified that in the modern post-industrial world, there are strict laws restricting the free game of supply and demand, subordinating it to the system of «totalitarian sociodynamics». Acts of personalized choice and consumption are subjectively experienced as freedom, but the "magic of the system» is that the uniqueness and personalization of free choice are realized through the combinatorics of initially provided and fixed - in the idea of the model - serial differences. Contrary to its appearance and the political myths of liberal democracy, the system of supply and demand is not nominalistic in its structure, but Platonic-Hegelian, asserting the ontological, epistemological, axiological and logical-semantic primacy of the general and the serial over the individual and the unique. At the same time, the system of totalitarian sociodynamics determines not only the state of the market of goods and services, but also the development of human "essential forces»: abilities and talents, inclinations and talents, qualities and properties, etc. Fromm notes that «the market determines the price or value of certain personal qualities, and even determines their very existence. If the qualities that a person can offer are not in demand, then he has no qualities at all» $[5$, p. 149]. But this means that the condition for successful adaptation to a market economy is the functional, instrumental, utilitarian, etc. attitude of the agent of this economic system to his own human qualities.

The process of cognitive, purposeful and systematic formation of personality within the framework and under the control of social institutions, i.e. education involves the inclusion of a person in the socio-cultural space, the development of historical and cultural values, landmarks, traditions, customs, the conversion of a sense of duty, openness to other people, their people and edema. The main social function of education is to create a system and mechanisms for the transmission from generation to generation of knowledge of worldview orientations and ideas that reflect the original form of the people's worldview and perception of the world, social description, norms and management skills.

Complementarity with the social environment, the first basic knowledge about it, a person receives in the family. It is in the family that the foundations of knowledge, relationships, and beliefs are laid. It should be noted that the value of the family as a social institution for a long time is unworthy of learning. Not so long ago, in our society, dream gifts with a family of diligence were undertaken to educate the future citizen, transferring this function to schools, labor collectives, sociable organizations, etc. All this could not but cause serious collections both in the general (public) and personal (private) lives of people. The next important name in education is the period of a person's education in school and other educational institutions. As young people grow and prepare for their civic duty, the body of knowledge they acquire becomes more complex. On the other hand, not all of them acquire the character of consistency and completeness. Today, the mass mediaprint, radio, and television-are a powerful tool for educating citizens. They carry out intensive processing of the general opinion, its formation. At the same time, the implementation of not only creative, but also destructive tasks takes place. It would not be an exaggeration to say that the name media is in many ways the anti- 
humanistic phenomenon that has been so rich in the past two decades.

Unfortunately, today we are witnessing the process of applying political technologies of mind manipulation. S. G. Kara-Murza, analyzing mind manipulation as a special type of management and technology for the exercise of political power, gives it the following definition: "Manipulation is a method of domination by spiritual influence on people through programming their behavior. This influence is directed at the mental structures of a person, is carried out covertly and aims to change the opinions, motives and goals of people in the right direction for the authorities» [6, p. 32]. Next S. G. KaraMurza emphasizes that the manipulation of consciousness arises and becomes the predominant political technology only with the establishment of socio-political orders based on representative democracy of the Western type. But by taking away a person's ability to think independently and critically, rationally develop their own opinion, this type of technology destroys the autonomy of the individual, thereby undermining the value-ontological foundation of Western civilization. In other words, the paradigm of the effectiveness of political technologies and the paradigm of socio-humanitarian priorities of the administration of political power in modern political theory and in the practice of political action are no longer mutually exclusive, but enter the field of explicitly expressed relationships and interdependencies.

In modern life, we observe a situation where the ideological and spiritual and moral potential of specific individuals, socio-political organizations and groups, production collectives do not take a solid system-forming basis, i.e., in systems of value orientations and preferences, in the individual, group and spiritual order. there is no internal interconnection, mutual cooperation and mutual enrichment in the public living space. Experience, both historical and daily, shows that not all and not all problems of everyday life can be solved by bringing them under the material and financial basis. The race for material treasures can make life secure, but it is unlikely to be rich. For the true wealth of a person is inseparable from the reality of the soul, from the sometimes invisible connection with the past, the orient of his kind, the history of his people. The analysis shows that there is a direct correlation between material wealth and the spiritual state of the individual, the standard of living and social responsibility of a person, his mercy, compassion for his neighbor, the preservation of debt to the Motherland and foreign. And without this, he is only a consumer and lives (does not live) in the space in which his own self-interest and selfishness rule - the easterners of eternal devils, envy, distrust, predation... The danger of such a situation, both for the formation of personal characteristics of a person, and for the process of education is obvious. It should be emphasized that the key to achieving this kind of consistency is to get every citizen to the spiritual values. A person exalts not material wealth (money), but the wealth and depth of his spiritual world, the degree of development of humanistic beliefs, charity, love and respect for people.

Spirituality as a system-forming foundation of human existence is also the Eastern strengthening of culture as a form and ability of self-realization of the civil side. The educational process in this direction should be developed on the basis of those basic values of reference points that reflect the historical, cultural, spiritual and moral traditions of the settlement of Kazakhstan. Otako - a large set of existing and proposed socio-political and culturaleducational programs are compiled outside of the civilization that they should develop and adapt to the needs of modernity.

Modern civilization unceremoniously intrudes into the folk lifestyle. It «knocks» a person out of the previous rhythm not only in the physical sense, but also in the spiritual sense. This can be countered only through the actualization of their cultural traditions. This is, in our opinion, the most effective way to give education meaninglife guidelines and content. A people's need to live at their own discretion, not to lose their identity, to preserve their soul, 
to resist the headless innovations issued for spiritual and aesthetic achievements. «There are outwardly prosperous epochs», writes N. Berdyaev, "when there is stability in times and everyone is aesthetically interested in a strong position in it. But there are disastrous epochs, when there is no solitude and solidity in the times, when there is nothing to lean on, when the waves waver under your feet. And here in the taxi era ... the strength of a person is determined only by his spiritual rootedness in eternity. A person learns what he brings, not only time, but also eternity, not only to the world, but also to God « [7]. And it is necessary to start the process of «spiritual rooting into eternity» with the first days of the child's birth, with the design of baby strollers, toys in nurseries, kindergartens, with fairy tales-this is one of the best not only cognitive, but also educational means in the child-about peace, friendship, love. And extend this in the design of school classes, teachers, etc.

In solving the problem of the formation of knowledge, alienation, conduct and Activity, it is important to determine the centers of attraction of people's interests, what concepts they define them, and what meaning they put in them. Such centers can be noted for the interest of people and their attitude to the historical past, socio-political real and innovative future of Kazakhstan. It is on this basis that the ideology of modern human education should be formed. The main thing in it should be that it is designed to determine its effectiveness, orientation and relevance, namely, the image of the Motherland as the spiritual and moral defender of all Kazakhstanis, the orientation to its arrangement and the well-being of its citizens. "Without love for his land," N. Berdyaev said, "a person is powerless to take possession of the land»[8].

The concept of human capital can be seen as a reflection of the researcher's growing interest in the anthropological problem and ponymania of the personal significance of a person's self-esteem. In the XX century, the whole series of contradictions and paradoxes in the systems «man-nature- society» was revealed. These contradictions and paradoxes have included an increase in the "anthropological tension» in social cognition, an emphasis in various types of research on the problem of man's essence, the prospect of development and independence of his existence. A positive decision of such an outsider, to his needs and expectations, can be considered the emergence and spread of the concept of humanitarian (anthropological) expertise as a systematic effectiveness in identifying and evaluating factors that are not difficult for a person to assess. The duration of life and death rates, income and occupation of the population, the stability of the environment and regional disparities in economic development, variations in the structure of local self-government and the dynamics of the process of formation of civil society are the main components of human capital.

The main resource of the modern community is information. If in the industrial community capital was the stimulating or limiting factor in the development of the community, then today in the postindustrial society knowledge appears as this factor. In an industrial society, it was possible to own capital without being competent in the laws and mechanisms of its use. Today, in a post-industrial society, mastering an intellectual product does not give anything, most likely you need to be able to use them. The ability to use an intellectual product with varying degrees of effectiveness is formed in the process of education. It should also be taught that knowledge and information cannot, with acceptable material resources, be generated with guaranteed success as a result of economic coercion. A creative person who is able to create a unique intellectual product cannot be formed in a short time, using mobilization methods. The desire for new knowledge, from which the subject of the information community grows and develops, should be a strong personal motivation.

The interests and values that correspond to the creative personality are laid down from childhood, formed during the dialogue of generations, as well as through 
the influence of educational institutions. In modern conditions, education should have a completely different meaning. It should be a «basic» phenomenon. Today, we can see that in economically developed countries so much attention is paid to the problems of education: general strategy, financing, variability, ensuring continuity. Education is considered as a productive way to increase the human potential of society, and the importance of this process is justified not only by the economic benefits associated with overcoming the functional illiteracy of the population and acquiring the necessary skills by the labor force. Every effort is made to emphasize the social effectiveness of education, which allows people to innovate in their lives and work, competently build relationships with other people, and actively participate in making decisions that affect their future. First of all, among the expected learning outcomes is the development of the inner activity of the individual. And this, in turn, forms a person's self-esteem and a sense of satisfaction, which enable an adult to realize new projections of his personality on the environment, is thought to be a factor in the development of human capital. In the opinion of J. Dewey, the social effectiveness of education should not be reduced to the direct and qualified performance of official duties, since its main components are certain human qualities - reasonable empathy, good will, the desire to make your own internally significant experience useful and important for other people. Such results of education, according to the philosopher, can contribute to the growth, development and preservation of democracy [9, p. 117-118].

Such an ethical principle is unattainable for the majority. Even in the developed countries of the modern world, these socalled ideal results of education have not yet been fully achieved. This is due to the fact that the European educational model, aimed primarily at the formation of a «knowledgeable person», is based on ethical neutrality. But in an environment of economic and social stability, the axiological insufficiency of the current model of education can be compensated by the basic values and axioms of culture that remain in society (the national idea, national symbols, age-old traditions, the values of the family, a healthy lifestyle).

\section{Conclusion}

In the formation of a knowledge society, the role of education is of particular importance, since the main resource of such a society, along with information, is knowledge. Everyone knows that in the process of education, a person develops certain skills and abilities to effectively use and increase the intellectual product.

Modern education and upbringing of the individual should form a picture of the world that ensures the orientation of the individual in various life situations, including in a situation of uncertainty, It is necessary to recognize that today the human environment is significantly changing. The information environment is dominant, and the social and industrial take on a different meaning in human life than before. We are witnessing how modern man faces the future, which is so unknown that it is difficult to predict the development of both natural and social processes.

The processes taking place in the modern conditions of human creation, i.e. in the information community, will lead to the formation of a new type of person, for whom the need for creativity, selfdevelopment and self-change will acquire, if not dominant, then unconditionally significant character. A person of the post-industrial community will have to demonstrate the ability to build rather than copy, to become an independent entity, since the information environment requires great intellectual mobility.

The essence of education in modern society is reduced to the versatile development of the individual and the realization of the personal potential of the younger generation. The reforms and modernizations taking place today in all spheres of life of our society-science, politics, economy, culture, building on the restoration of the personal principle 
in society. Knowledge, skills and abilities as human resources in modern concepts are considered not as whole education, but as its important assets, which ensure the achievement of the main educational whole - the education of an initiative, active person with a pronounced creative personality, a highly moral, free person, a responsible citizen of a democratic society.

\section{References}

1 Panarin A.S. Filosofiya politiki. Uchebnoe posobie dlya politologicheskih fakultetov i gumanitarnyih vuzov [Philosophy of politics. Textbook for political science faculties and humanities universities]. - M.: Novaya shkola, 1996. - 424 s. (in Russ)

2 Bauman Z. Razveya storozh bratu moemu? [Am I my brother's keeper?] // Bauman Z. Individualizirovannoe obschestvo. - M.: Logos, 2002. - S. 89-103. (in Russ)

3 Kant I. Ideya vseobschey istorii vo vsemirno- grazhdanskom plane [The idea of universal history in the world-civil plan] // Kant I. Soch.: V 6 t. T. 6. - M.: Myisl, 1966. - S. 5-23. (in Russ)

4 Gegel G.V.F. Filosofiya prava [Philosophy of law] // Gegel. Sochineniya. Tom VII. - M.-L.: Sotsekgiz, 1934. - 380 s. (in Russ)

5 Fromm E. Begstvo ot svobodyi [Flight from freedom] // Fromm E. Begstvo ot svobodyi; Chelovek dlya sebya. - Mn.: OOO «Popurri», 1998. - S. 3-366. (in Russ)

6 Kara-Murza S.G. Manipulyatsiya soznaniem [Manipulation of consciousness]. M.: EKSMO-Press, 2002. - 832 s. (in Russ)

7 Berdyaev N.A. Tsarstvo Duha i Tsarstvo Kesarya. Ekzistentsialnaya dialektika. [The Kingdom of the Spirit and the Kingdom of Caesar. Existential dialectics]. - M.: MGU, 1980. (in Russ)

8 Berdyaev N.A. Sudba Rossii. Reprintnoe vosproizvedenie izdaniya $1918 \mathrm{~g}$. [The Fate of Russia. Reprint reproduction of the 1918 edition] - M.: MGU, 1980. - S. 121. (in Russ)

9 Dyui Dzh. Demokratiya i obrazovanie [Democracy and education]. - M., 2000. (in Russ)

\section{INFORMATION ABOUT AUTHORS}

Ayazhan Sagikyzy

Maira Shurshitbai

Zebiniso Akhmedova

Аяжан Сагикызы

Майра Шуршитбай

Зебинисо Азизовна Ахмедова

Аяжан Сағиқызы

Майра Шүршітбай

Зебинисо Азизовна Ахмедова
Professor, Doctor of Philosophical Sciences, Chief Researcher, Al-Farabi Kazakh National University, Institute for Philosophy, Political Science and Religious Studies of the CS MES RK, Almaty, Kazakhstan

PhD student, Sarsen Amanzholov East Kazakhstan University, Ust-Kamenogorsk, Kazakhstan

Candidate of Philosophical Sciences, Associate Professor, Bukhara State Medical Institute, Bukhara, Uzbekistan

профессор, доктор философских наук, главный научный сотрудник, Казахский Национальный университет имени аль-Фараби, Институт философии, политологии и религиоведения КН МОН РК, Алматы, Казахстан

докторант, Восточно-Казахстанский университет имени С. Аманжолова, Усть-Каменогорск, Казахстан

кандидат философских наук, доцент, Бухарский государственный медицинский институт, Бухара, Узбекистан

профессор, философия ғылымдарының докторы, бас ғылыми қызметкер, Әл-Фараби атындағы Қазақ ұлттық университеті, ҚР БҒМ ҒК Философия, саясаттану және дінтану институты, Алматы, Қазақстан

докторант, С. Аманжолов атындағы Шығыс Қазақстан университеті, Өскемен, Қазақстан

философия ғылымдарының кандидаты, доцент, Бұхара мемлекеттік медицина институты, Бұхара, Өзбекстан 